\title{
Quantifying edge influence on plant community structure and composition in semi-natural dry grasslands
}

\author{
Rocco Labadessa (iD, Audrey Alignier, Stefania Cassano, Luigi Forte \& Paola Mairota
}

\author{
Keywords \\ Alta Murgia; Boundary attribute; Depth of edge \\ influence; Edge dynamic; Edge effect; \\ Grassland conservation; Habitat \\ fragmentation; Magnitude of edge influence \\ Abbreviations \\ DEI = Depth of edge influence; EIV = Ellenberg \\ Pignatti indicator values; $\mathrm{MEI}=$ Magnitude of \\ edge Influence. \\ Nomenclature \\ Conti et al. (2005) for vascular plants, Mucina \\ et al. (2016) for plant communities \\ Received 9 December 2016 \\ Accepted 16 July 2017 \\ Co-ordinating Editor: Ralf Ohlemuller
}

\author{
Labadessa, R. (corresponding author, \\ rocco.labadessa@uniba.it) ${ }^{1}$, \\ Alignier, A. (audrey.alignier@inra.fr)², \\ Cassano, S. \\ (stefania.cassano86@gmail.com) ${ }^{3}$, \\ Forte, L. (luigi.forte@uniba.it) ${ }^{3,4}$, \\ Mairota, P. (paola.mairota@uniba.it) ${ }^{1}$ \\ ${ }^{1}$ Department of Agri-Environmental and \\ Territorial Sciences, University of Bari, Via \\ Orabona 4, 70125 Bari, Italy; \\ ${ }^{2}$ INRA, UMR 0980 BAGAP, 65 rue de St Brieuc \\ CS 84215, 35042 Rennes Cedex, France; \\ ${ }^{3}$ Department of Biology, University of Bari, Via \\ Orabona 4, 70125 Bari, Italy; \\ ${ }^{4}$ Botanical Garden and Museum of University \\ of Bari, Via Orabona 4, 70125 Bari, Italy
}

\begin{abstract}
Aims: We investigated the influence of anthropogenic boundaries on semi-natural grassland plant communities in terms of: (1) depth and magnitude of edge influence and (2) changes in plant community composition associated with boundary attributes.
\end{abstract}

Location: Alta Murgia, Puglia, southeast Italy.

Methods: Sampling sites were selected taking into account three boundary attributes thought to be most important in the study area, i.e. adjacent land use, presence/absence of stone wall at the patch boundary and occurrence of slope. Plant communities were surveyed along 40-m transects perpendicular to the patch boundary. Each transect was divided in six plots at given distances from patch boundary. Data were collected related to a set of plant community descriptors referring to structure, composition, life history traits and ecological attributes. A novel methodology that relies on the definition of inner plots as relative interior habitat was introduced for assessment of the depth and magnitude of edge influence. DCA was then used to characterize edge communities.

Results: Significant edge influence on grassland plant communities was limited to the adjacent boundary $(<2.5 \mathrm{~m})$. For the majority of descriptors, magnitude of edge influence was higher in grasslands adjacent to crops rather than to roads, in sloping rather than flat edges, and in wall-bounded rather than unbounded patches. Plant assemblages dominated by either ruderal species or xerothermic grassland species were, in all cases, associated with unbounded edges, while distinct assemblages were observed in wall-bounded plots according to their different morphology. Wall-bounded sloping edges were characterized by woodland species, whereas their non-sloping analogues were associated with calcareous grassland species.

Conclusions: Our findings provide new insights into the influence of anthropogenic boundaries on semi-natural dry grassland by assessing the depth and magnitude of edge influence, as well as the changes in composition of edge plant communities as a function of the combination of boundary attributes. While the method implemented enabled us to address many of the issues experienced in quantification of edge influence in herbaceous communities, it also allowed us to demonstrate the major role of boundary attributes in modulation of edge community patterns.

\section{Introduction}

Semi-natural grasslands of the Western Palaearctic region are considered among the most species-rich habitats in the world (Dengler et al. 2012), where biodiversity had incrementally increased during millennia of extensive land-use and management practices, including grazing and deliberate burning regimes (Willems 1990; Turbé et al. 2010; Dengler et al. 2014). Vascular plant diversity of certain European grasslands even exceeds that of 
tropical rain forests (Wilson et al. 2012), traditionally thought to be the most diverse ecosystems on Earth. Today, many of these semi-natural grassland ecosystems of high conservation value are threatened by dramatic landuse changes associated with the current socio-economic and political context in Europe (Cousins \& Eriksson 2008). Land-use change is one of the main factors responsible for the loss, modification and fragmentation of habitats (Wiens 1992; Forman 1995).

As a direct consequence of fragmentation, the increasing extent of patch boundaries leads to a series of specific habitat modifications, the so-called edge influence, which may have strong consequences on habitat and community structure and on their dynamics (Saunders et al. 1991; Forman 1995; Laurance et al. 2002; Cadenasso et al. 2003). When compared with interior habitat, communities at the boundary zone (edge; cf Forman 1995) commonly show significant variation in species richness and diversity (Risser 1995; Ries et al. 2004), becoming richer in generalist and invasive species (Brothers \& Spingarn 1992; Cadenasso $\&$ Pickett 2001) but also representing invaluable refugia for rare or edge-specialist organisms (MacArthur $\delta$ MacArthur 1961; Berg \& Part 1994; Ries \& Sisk 2010).

These effects on biodiversity, as well as many other edge-related patterns, are further modulated by boundary attributes, e.g. related to morphology and origin (Forman 1995). Adjoining land-use type and slope, as much as the presence/absence of barriers are key features in modulating edge ecological patterns (e.g. Saunders et al. 1991; Harper et al. 2005; Jansson 2009). For example, being adjacent crops leads to an increase in nutrient inputs at the edge, which may favour the growth and dispersal of nitrophilous plant species (Pocewicz et al. 2007), while roadside edges are likely to be colonized by non-native plant species (Forman \& Alexander 1998; Hansen \& Clevenger 2005). Changes in water, light and nutrient availability along sloping edges act as direct drivers of plant growth and vegetation dynamics (Beatty 1984; Matlack 1993; Fox et al. 1997). The occurrence of abiotic barriers to migration and/or seed dispersal, such as walls or ditches, is also crucial in modulating exchanges among ecosystems (Mader et al. 1990; Higgins et al. 2003). Therefore, a thorough understanding of edge patterns in relation to the role of boundary attributes is required for the assessment of conservation strategies for fragmented semi-natural habitats.

Despite increasing efforts for the conservation of European semi-natural grassland ecosystems, current theories and methods for investigation of edge-related patterns mostly rely on studies from forest edges (e.g. Ranney et al. 1981; Chen et al. 1992; Harper \& Macdonald 2001), where grasslands only play a minor role when considering the forest-grassland interface (e.g. Camarero et al. 2000;
Breshears 2006; Alignier \& Deconchat 2013). Approaches traditionally taken to assess the depth and magnitude of forest edge influence may show significant limitations when applied to different types of vegetation. Most approaches require the pre-definition of independent reference sites representing the homogeneous interior habitat (Chen et al. 1992; Didham \& Lawton 1999; Harper \& Macdonald 2001). However, such pre-definition of interior habitat is not always straightforward in mosaic herbaceous communities, for example in many rocky and stony seminatural grasslands. While many vegetation types may show rather constant structural and functional community patterns across different sites and scales, this is not the case for many forms of herbaceous vegetation that are known to be naturally heterogeneous and variable in spatial and species arrangement (Giladi et al. 2011; Dengler et al. 2014; Turtureanu et al. 2014).

In this context, our aim was to investigate the influence of anthropogenic boundaries on the structure and composition of grassland plant communities of Alta Murgia (southeast Italy) in order to provide new insights for assessment of conservation strategies for protected seminatural grasslands. More specifically, we used a comparative approach to assess (1) the depth and magnitude of edge influence and (2) changes in plant community composition associated with boundary attributes.

\section{Methods}

\section{Study area}

This study was carried out in the central portion of Alta Murgia $\left(40.985^{\circ}-40.885^{\circ} \mathrm{N}, 16.470^{\circ}-16.570^{\circ} \mathrm{E}\right)$, a calcareous plateau in southeast Italy and partly included within the Natura 2000 site "Murgia Alta" and the National Park "Alta Murgia". Ranging from 300 to 700 m a.s.l., this area is primarily characterized by its compact platform of Cretaceous limestone, with very shallow and rocky soils and total lack of surface water courses. The climate is typically sub-mediterranean, with annual temperatures from $7{ }^{\circ} \mathrm{C}$ in Jan to $25^{\circ} \mathrm{C}$ in Jul/Aug, and rainfall mostly in autumn-winter, of 570 and $700 \mathrm{~mm} \cdot \mathrm{yr}^{-1}$ with occasional snowfall above $500 \mathrm{~m}$ a.s.l. The phytoclimate is semi-continental, with meso-mediterranean thermo-type, ombro-type, from dry to sub-humid, and growing season bound by both winter temperature and summer drought (Forte et al. 2005).

With the exception of residual patches of downy oak (Quercus pubescens s.l.) woodland and Aleppo pine (Pinus halepensis) plantations, the upper part of the plateau is mainly covered with semi-natural dry grasslands. Substantial losses of this ecosystem occurred between 1990 and 2000, mainly due to the increase in durum wheat production (Boccaccio et al. 2013). To date, grasslands cover 
$\sim 29800$ ha and represent what remains of the $\sim 80000$ ha existing at the beginning of the 20th century (Mairota et al. 2013).

Among the most interesting grassland plant communities occurring in this area, those belonging to the endemic alliance Hippocrepido glaucae-Stipion austroitalicae (class Festuco-Brometea, order Scorzoneretalia villosae) are listed in Habitat Directive 92/43/EEC (Natura 2000 code: 62A0). These grasslands are primarily characterized by the endemic feather-grass Stipa austroitalica (Annex II Habitat Directive), and host a remarkable set of species of biogeographic concern, e.g. the endemic taxa Thymus spinulosus, Helianthemum jonium, Centaurea deusta subsp. deusta, Carduus micropterus subsp. perspinosus, Dianthus garganicus and Iris pseudopumila (Forte et al. 2005).

\section{Sampling design}

We collected plant data during Apr-May 2013 within 16 grassland sites (mean patch size $=248.6 \pm 136.9$ ha; see also Appendix S1). These sites had all been similarly subjected to grazing and periodic light summer burning and are still actively managed through extensive sheep grazing. They were selected considering a range of boundary conditions representative of the study area. We considered two alternatives for the three boundary attributes thought to be the most important in the study area: adjacent land use (annual crop or road), presence/absence of stone wall at the patch boundary, and inclination of the grassland towards the boundary on a slope $>25^{\circ}$ (steep or flat boundary). We selected two sites for each combination of attributes, so that each option was represented in $50 \%$ of the sites.

Within each of the 16 sites we surveyed plant communities from six non-adjacent plots $(2.5 \mathrm{~m} \times 0.5 \mathrm{~m})$ along a 40-m transect perpendicular to the patch boundary. The six plots were laid at given distances from the patch boundary $(0-40 \mathrm{~m})$ with their longer side parallel to the patch boundary and according to a geometric sequence (ratio 2): $\mathrm{A}=0 \mathrm{~m}, \mathrm{~B}=2.5 \mathrm{~m}, \mathrm{C}=5.0 \mathrm{~m}, \mathrm{D}=10.0 \mathrm{~m}, \mathrm{E}=20.0 \mathrm{~m}$ and $\mathrm{F}=40.0 \mathrm{~m}$ (Fig. 1).

A set of plant community descriptors, i.e. referring to structure, composition, life history traits and ecological attributes, was then used for the subsequent analyses. Cover values of vascular plant species (\%) were recorded in each plot and used to compute species richness (S), Shannon index $\left(\mathrm{H}^{\prime}\right)$ and Simpson index $(\lambda)$. Mean height of the grass layer $(\mathrm{cm})$ was also noted in the field. Species were classified according to nine life-form categories based on Raunkiaer's (1934) classification: phanerophytes (Phan), chamaephytes (Cham), perennial grasses (H grass), perennial forbs ( $\mathrm{H}$ forb), biennials ( $\mathrm{H}$ bien), annual grasses (T grass), annual forbs ( $\mathrm{T}$ forb), bulbous geophytes ( $\mathrm{G}$ bulb), rhizomatous geophytes ( $\mathrm{G}$ rhiz). Ellenberg-Pignatti indicator values (EIV; Pignatti et al. 2005), weighted by plant species cover, were also computed for plots. EIVs are based on ecological requirements and specific plant traits of adaptation to light $(\mathrm{L})$, temperature $(\mathrm{T})$, continentality $(\mathrm{C})$, moisture $(\mathrm{H})$, soil $\mathrm{pH}(\mathrm{R})$ and nutrients $(\mathrm{N})$.

\section{Statistical analysis}

A methodological modification was introduced to the conceptual framework presented by Harper \& Macdonald (2001) for quantification of the depth and magnitude of edge influence because the heterogeneous spatial and species arrangement of the studied herbaceous communities hindered pre-definition of interior habitat, which is usually needed for assessment of edge influence. In particular, the novelty of the method consists in the comparison of each vegetation plot with the set of inner plots relative to it, therefore representing a comparative, rather than an absolute reference for interior habitat.

For each community descriptor we first computed the mean value among plots surveyed at the same distance. Then we used ANOVA (using SPSS 16.0; SPSS, Chicago, IL, US) to compare the plot mean with the mean of subsequent inner plots, which represents its relative interior habitat. For instance, the mean of A plots was compared with the mean of all plots from $B$ to $F$, then the mean of $B$ plots was compared with the mean of plots between $\mathrm{C}$ and $\mathrm{F}$, etc. Least square difference (LSD) post-hoc test was used to identify pair-wise significant differences between means. Significance threshold was selected at $P<0.05$. When evaluating edge influence we considered only consecutive significant variations, moving from boundary to interior. Conversely, the significant values that are discontinuous along the gradient were not regarded as directly influenced by the boundary.

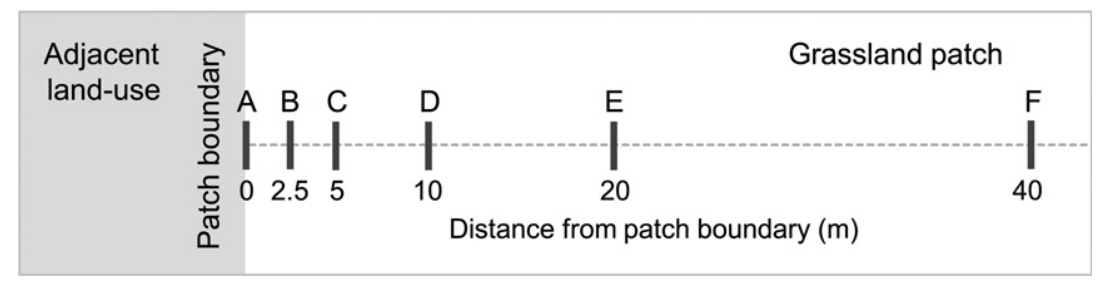

Fig. 1. Scheme of plots distribution along the gradient of distance from patch boundary. 
The series of consecutive plots (distances) showing a significant difference from their relative interior habitats allowed estimation of the depth (distance) of the edge influence (DEI; Chen et al. 1992; Forman 1995; Cancino 2005; Harper et al. 2005; Ewers \& Didham 2006). For each variable, the magnitude of edge influence (MEI) was defined as the maximum difference between plots and their relative interior habitat (Chen et al. 1992; Burton 2002; Harper et al. 2005; Ewers \& Didham 2006). As the effect of the boundary may determine an increase or a decrease of the value of each descriptor, we also noted the sign $(+/-)$ of the difference between plots and their relative interior habitat. In order to evaluate variations associated with a particular boundary attribute rather than associated with the edge itself, we used ANOVA followed by LSD post-hoc test separately on each of the half-data sets (eight plots) based on the alternative options occurring for each boundary attribute (land use, wall, slope).

In order to define plant assemblages associated with edge attributes, we applied DCA for the ordination of species occurring at patch boundaries (A plots). Both species presence/absence data and the 16 plots were simultaneously ordered. To derive information for the interpretation of ordination axes, Kruskal-Wallis Chi-squared test $\left(\chi^{2}\right)$ was then performed between species scores along the two DCA first axes and species EIV. DCA and $\chi^{2}$ tests were performed using $\mathrm{R}$ 3.2.3 (R Foundation for Statistical Computing, Vienna, AT).

\section{Results}

In total, 291 vascular plant species were recorded, mostly belonging to the Poaceae ( 39 species), Asteraceae (37 species) and Fabaceae (31 species). Mean species richness $( \pm$ SD) was $103.70 \pm 13.50$ for sampled sites and $41.42 \pm 11.17$ for plots. Life-form assortment was largely dominated by therophytes $(50.4 \%$ ) with a high proportion of hemicryptophytes (19.5\%) and geophytes (15.7\%).

Changes in the mean of descriptor values were found along the gradient of distance from the grassland boundary. For instance, Fig. 2 shows the variation of mean grass height, light value and annual forb cover at increasing distance from the grassland boundary as examples of grassland structure, EIV and life form (see also Appendix S2).

\section{Depth and magnitude of edge influence}

The comparison between the mean of descriptor values per plot and the mean of subsequent inner plots resulted in significant changes among plant communities located within the shortest distances from the grassland boundary $(0 \mathrm{~m}<\mathrm{DEI}<2.5 \mathrm{~m})$. For most parameters, MEI was generally higher in grasslands adjacent to crops rather than to roads, in sloping rather than flat edges, and in wallbounded rather than unbounded patches (Fig. 3).

With regard to the overall data set, a significant increase in grass height, humidity, phanerophytes, perennial forbs and annuals was found in plots nearest to the boundary, whereas values for light and rhizomatous geophytes increased significantly in innermost plots. In general, no significant change in species richness and diversity, or the EIV for temperature, continentality, $\mathrm{pH}$ and nutrients, or in chamaephyte and bulbous geophyte cover was found along the gradient (Fig. 3).

When considering the adjacent land use, we found significant changes in annuals and rhizomatous geophytes at boundaries bordering arable crops, while the perennial forbs value was seemingly influenced by proximity to a road (Fig. 3). The occurrence of a stone wall was associated with a larger increase in grass height and higher cover of biennials. There was a significant change in EIV for soil moisture and cover value of grasses and rhizomatous geophytes in unbounded patches. Phanerophyte cover increased at patch boundaries if protected by a wall, but decreased when the wall was absent (Fig. 3). A significant increase in perennial forb cover was observed along sloping boundaries, while higher cover values of phanerophytes, annual grasses and rhizomatous geophytes were found along flat boundaries (Fig. 3).

\section{Edge plant community composition}

The ordination of plant species occurring immediately adjacent to patch boundaries (plots $\mathrm{A}$, distance $=0 \mathrm{~m}$ ) enabled us to obtain distinct relationships between boundary attributes and plant assemblages. The two-first DCA components were considered as they accounted for $63.08 \%$ of the variance. The primary component reveals a gradient of increasing EIV for nutrients and decreasing for light and continentality (Table 1). The second component seems to be effective in segregating unbounded edges from those bounded by a stone wall. Plant assemblages dominated by either ruderal species (e.g. Malva multiflora, M. sylvestris, Erodium malacoides, Sisymbrium officinale, Bromus diandrus) or xerothermic grassland species (e.g. Cachrys ferulacea, Sedum rupestre, Rostraria cristata, Petrorhagia saxifraga) were associated with all cases of unbounded edges (Fig. 4).

Moreover, there were distinctive assemblages in wallbounded plots according to their different morphology. Wall-bounded sloping edges were characterized by woodland species (e.g. Q. pubescens, Rosa sempervirens, Osyris alba), whereas their non-sloping analogues were associated with calcareous grassland species (e.g. Festuca circummediterranea, Stipa austroitalica, Crupina crupinastrum, Charybdis pancration; Fig. 4). 

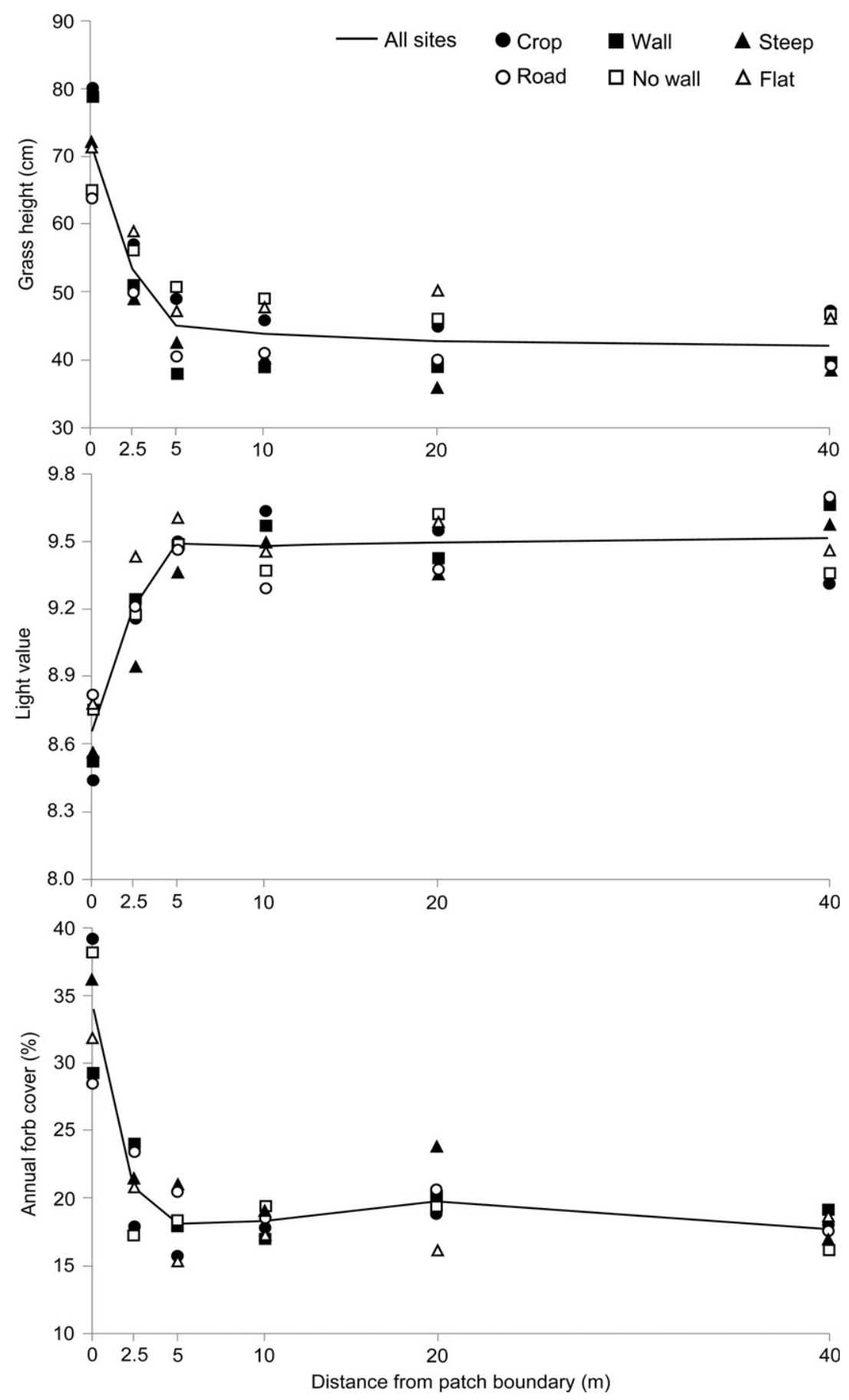

Fig. 2. Mean values of grass height, EIV for light and annual forb cover at increasing distance from patch boundary. Means are reported for all sites (line) and for selected boundary attributes (symbols).

\section{Discussion}

Depth and magnitude of edge influence

In this study we analysed changes in plant assemblages along a gradient of distance from anthropogenic boundaries in protected semi-natural dry grasslands. The methodological modification adopted (i.e. comparison of each plot with its relative interior) represents an original grassland-specific development of methods currently adopted for investigation of edge-related vegetation 


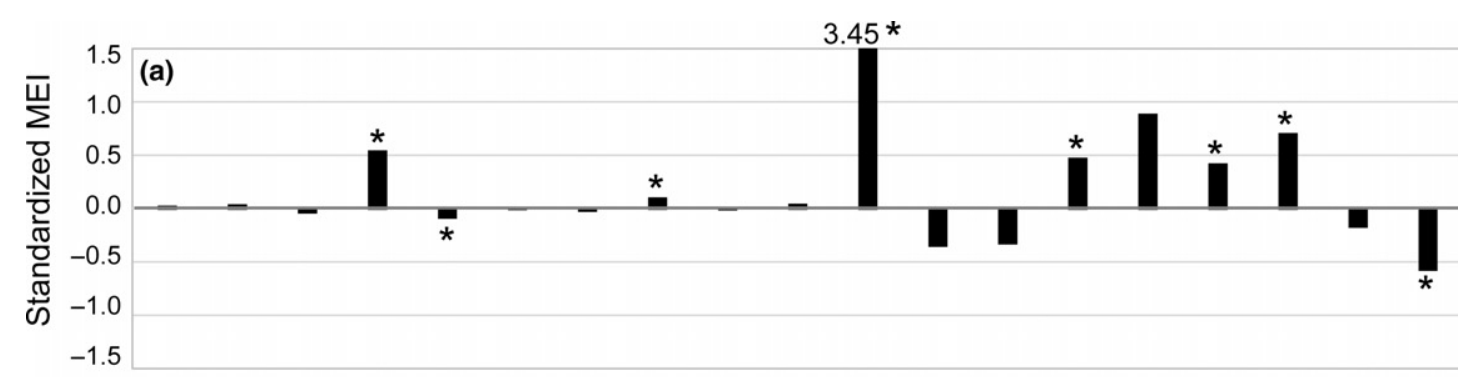

All
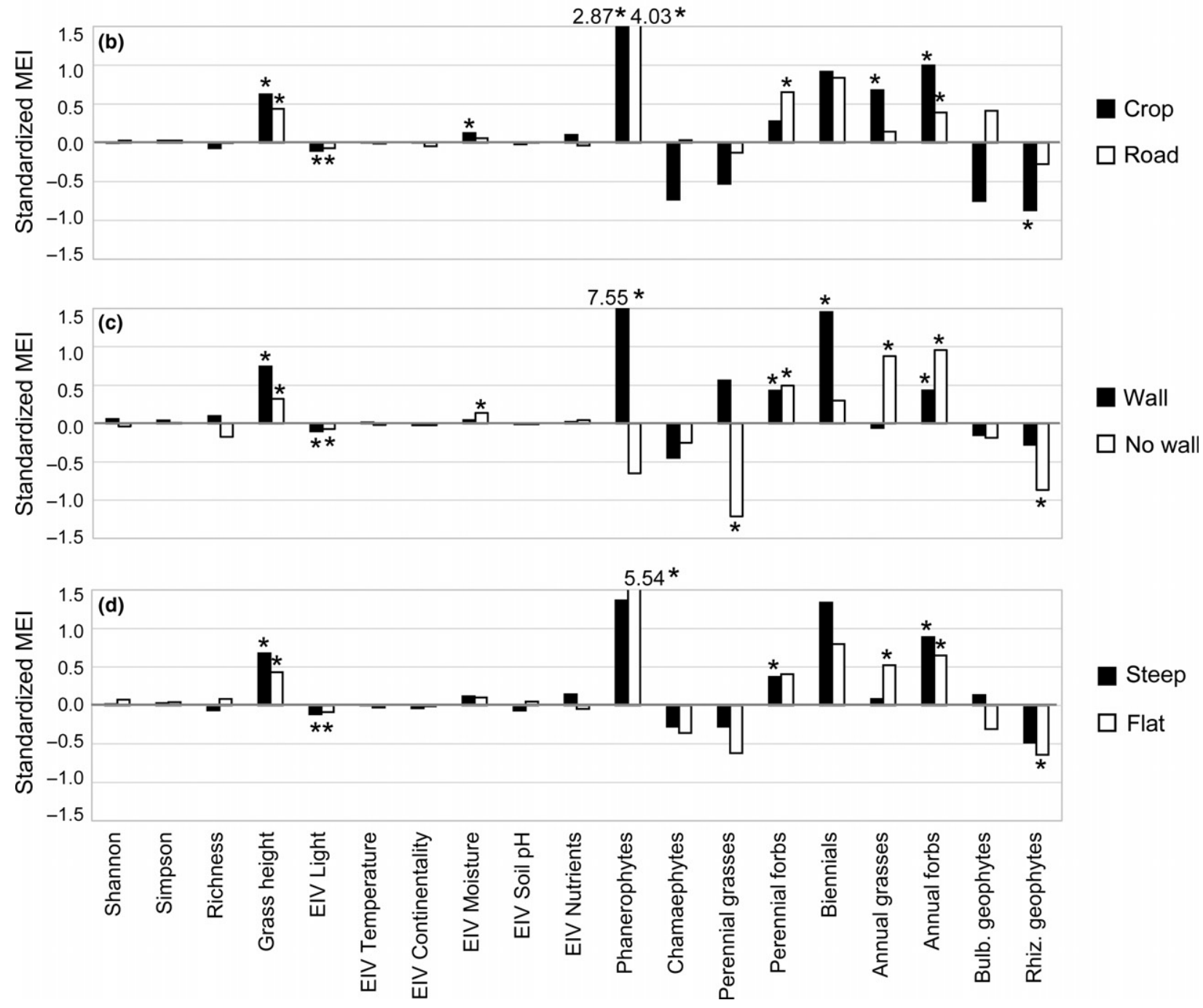

Fig. 3. Standardized Magnitude of Edge Influence (MEI) on selected community descriptors in the tested sites, according to all edges (a), adjacent land-use (b), presence of stone wall (c) and slope (d). Values out of range are reported as numbers above the column. Significant values are marked with an asterisk.

patterns. It allowed us to assess the importance (in terms of depth and magnitude) of edge influence on vegetation patterns in grassland plant communities.

Our approach does not require any a priori definition of a reference interior habitat, as such pre-definition can be problematic when considering mosaic herbaceous communities such as those occurring in many semi-natural dry grasslands (Giladi et al. 2011; Turtureanu et al. 2014). Therefore, this approach appears effective in overcoming some of the main issues regarding quantification of edge influence in grassland communities by rethinking the concept of reference interior habitat; here considered as the relative inner portion along the distance gradient. In fact, the definition of an arbitrary fixed reference distance 
Table 1. KruskaL-Wallis Chi-squared tests between species scores of DCA components and EIV.

\begin{tabular}{|c|c|c|c|c|c|c|}
\hline \multirow[t]{2}{*}{ EIV } & \multicolumn{3}{|c|}{ DCA 1st Component } & \multicolumn{3}{|c|}{ DCA 2nd Component } \\
\hline & $\chi^{2}$ & $d f$ & $P$ & $\chi^{2}$ & $d f$ & $P$ \\
\hline Light & $13.259^{\star}$ & 6 & 0.039 & 4.0615 & 6 & 0.668 \\
\hline Temperature & 9.107 & 8 & 0.333 & 4.322 & 8 & 0.827 \\
\hline Continentality & $11.291 *$ & 5 & 0.046 & 3.347 & 5 & 0.646 \\
\hline Moisture & 10.717 & 5 & 0.057 & 1.859 & 5 & 0.868 \\
\hline Soil pH & 5.419 & 8 & 0.713 & 6.705 & 8 & 0.568 \\
\hline Nutrients & $20.739^{\star}$ & 9 & 0.014 & 7.885 & 9 & 0.545 \\
\hline
\end{tabular}

*Significant values $(P<0.005)$.

(Chen et al. 1992; Brand \& George 2001; Hylander 2005) and identification of reference sites outside the studied gradient (Didham \& Lawton 1999; Harper \& Macdonald 2001) could thus be avoided.

Overall, we showed that the boundary itself had a significant influence on plant communities, although this effect was restricted to the shortest distance from the grassland boundary $(0 \mathrm{~m}<\mathrm{DEI}<2.5 \mathrm{~m})$. DEI is much smaller than that shown in the majority of studies on natural or anthropogenic forest edges (e.g. Ranney et al. 1981; Chen et al. 1992; Hibbs \& Giordano 1996; Harper \& Macdonald 2001), underlining the importance of scale-dependent factors when determining edge effects (Keitt et al. 1997; Turner et al. 2001). Moreover, our findings provide evidence of the fine-scale effects of habitat fragmentation within the

\section{(a) Sites}

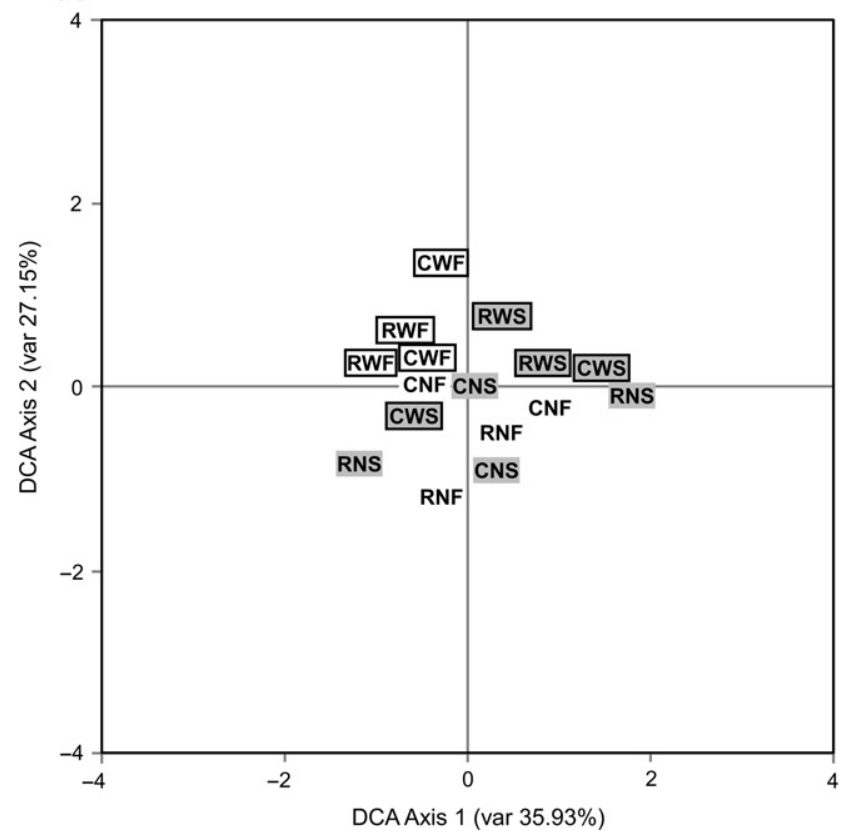

framework of its context-dependent effects on the quality of individual habitat patch at larger scales (Mairota et al. 2015; Wilson et al. 2016).

No distinct increase in overall plant species richness and diversity was detected at the grassland edge (edge effect sensu stricto), which is apparently in contrast to previous work on the interface between different ecosystems (Lovejoy et al. 1986; Risser 1995). These results may correspond to Van der Maarel's (1990) definition of ecotones, where no increase in species richness may occur due to important variations in environmental factors in the transition zone (Buisson \& Dutoit 2004; Dutoit et al. 2007). This pattern may also be explained in terms of a balance between positive and negative responses of single species, thus resulting in an overall neutral response at the edge (Ries et al. 2004). Moreover, boundary proximity may act as a driver of species competitive exclusion (Hardin 1960) rather than species addition dynamics. Indeed, when compared with forest undergrowth, denser and/or richer grassland communities can strongly reduce resource availability for incoming herbaceous species (Grime 1973; Davis et al. 2000).

However, boundary proximity was found to be associated with a general increase in herb height, forb proportion and humidity, as well as with a decrease in light value and cover of rhizomatous geophytes. These patterns indicate that the occurrence of encroachment by generalist and

(b) Species

- EIV $\mathrm{N}<3+$ EIV $\mathrm{N}>4$

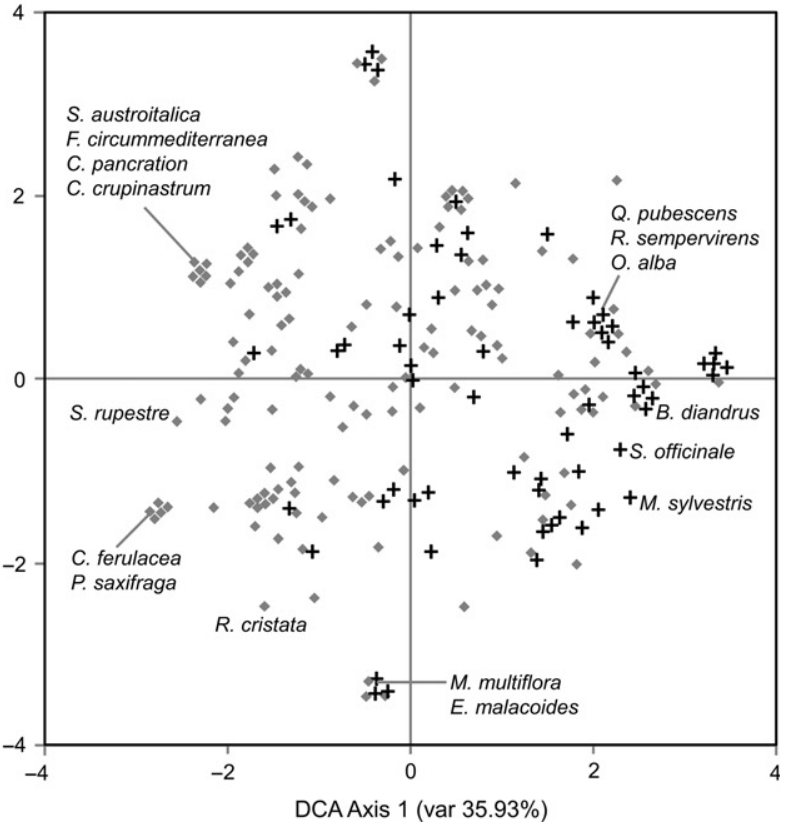

Fig. 4. Biplot of the DCA ordination of sites (a) and species (b). Sites are marked according to the combination of edge attributes: adjacent land-use type (C: crop; R: road); stonewall (W: wall; N: no wall); slope (S: steep; F: flat). Site boxes are highlighted in case of wall (outline) or steep slope (grey shade). Species are marked according to EIV N value (EIV $N<3$ in grey and EIV N $>4$ indicated by ' + '). Names are only reported for the plant species cited in the text. 
taller forb species at the boundary is detrimental to those species that are well adapted to dry oligotrophic pastures. This finding is in line with the assumption that anthropogenic margins tend to be richer in euriecious and invasive species (Forman 1995; Cadenasso \& Pickett 2001).

Important results were further achieved on the role of boundary attributes in modulating the strength (MEI) of descriptor variations, in accordance to previous work (Ries et al. 2004; Harper et al. 2005; Jansson 2009). For the majority of parameters, we found higher MEI in grasslands bordering crops rather than roads, in sloping rather than flat boundaries, and in wall-bounded rather than unbounded patches.

With regard to the vicinity of arable crops, we found a larger increase in annual forbs in both bounded and unbounded edges, which could indicate either direct encroachment of non-native annual species (across unbounded edges) or input of nutrients from cultivated areas (bypassing wall barriers; Pocewicz et al. 2007).

\section{Edge plant community composition}

The occurrence of stone walls was associated with contrasting vegetation patterns. In the case of sloping conditions, wall-bounded edges were richer in forest edge species, confirming that downstream stone walls may also act as a resource hub for more edaphically demanding species (MacArthur \& MacArthur 1961; Berg \& Part 1994; Ries \& Sisk 2010). As further evidence, phanerophytes increased at boundaries protected by walls, but decreased when walls were absent. These findings will be of interest for the evaluation and management of woody encroachment, which is considered an important issue for the conservation of grassland in the study area (Mairota et al. 2014) and in several other dry ecosystems (Chopping et al. 2008). In the case of flat morphology, edges were mostly characterized by typical grassland species (e.g. the protected feather-grass $S$. austroitalica), suggesting that stone walls may have a protective role in the plant communities studied. Therefore, when assessing the impact of human structures on grassland conservation status, stone wall barriers should be taken into account as either detrimental or protective elements, depending on the soil morphology.

With regard to unbounded edges, the lack of change in species assemblages was clearly explained by adjoining land-use type or slope, and plant communities of this type or boundary are characterized by a considerable number of species typical of over-grazed pastures. This finding suggests that coupled effects of boundary attributes and grazing intensity (including its variability through time) may occur. These need to be further investigated when assessing plant community changes associated with edge configuration, especially when considering extensive grazing management in fragmented landscapes (Dureau $\delta$ Bonnefon 1998; Buisson \& Dutoit 2004).

\section{Conclusions}

This work provides new insights on the influence of manmade boundaries on the structure and composition of semi-natural dry grassland of conservation concern. First, the depth and the magnitude of edge influence were quantified using a comparative approach, which enabled us to address many of the issues experienced in the quantification of edge influence in herbaceous communities. Second, changes in the composition of edge plant communities were assessed as a function of a combination of boundary attributes. The relevance of boundary attributes, with regard to their major role in the definition of multiple and contrasting community dynamics, should be taken into account together with other factors (e.g. grazing distribution and intensity) when planning land modifications and local management actions. Finally, all this information is needed for the assessment of conservation strategies aimed at dealing with the consequences of global loss and fragmentation of semi-natural habitats.

\section{Acknowledgements}

This research was partly carried out under a M.Sc. programme and did not receive any specific grant from funding agencies in the public, commercial or not-for-profit sectors. We wish to thank the Co-ordinating Editor and two anonymous reviewers for their constructive comments. RL, AA and SC conceived the ideas and designed the methodology; RL and SC collected the data; AA and RL analysed the data and led the writing of the manuscript; PM and LF tutored SC during her M.Sc. and critically contributed to the whole work and to the manuscript. All authors gave final approval for publication.

\section{References}

Alignier, A. \& Deconchat, M. 2013. Patterns of forest vegetation responses to edge effect as revealed by a continuous approach. Annals of Forest Science 70: 601-609.

Beatty, S. 1984. Influence of microtopography and canopy species on spatial patterns of forest understory plants. Ecology 65: 1406-1419.

Berg, A. \& Part, T. 1994. Abundance of breeding farmland birds on arable and set-aside fields at forest edges. Ecography 17: 147-152.

Boccaccio, L., Labadessa, R., Leronni, V. \& Mairota, P. 2013. Landscape change in the Natura 2000 "Murgia Alta" site and dry grassland fragmentation. In: Calabrese, G., Pacucci, C., 
Occhialini, W. \& Russo, G. (eds.) Proceedings of the IX National Congress on Biodiversity, Vol III, pp. 351-357. CIHEAM-IAMB, Valenzano, IT.

Brand, L. \& George, T.L. 2001. Response of Passerine birds to forest edge in coast redwood forest fragments. The Auk 118: 678-686.

Breshears, D.D. 2006. The grassland-forest continuum: trends in ecosystem properties for woody plant mosaics? Frontiers in Ecology and the Environment 4: 96-104.

Brothers, T.S. \& Spingarn, A. 1992. Forest fragmentation and alien plant invasion of Central Indiana old-growth forests. Conservation Biology 6: 91-100.

Buisson, E. \& Dutoit, T. 2004. Colonisation by native species of abandoned farmland adjacent to a remnant patch of Mediterranean steppe. Plant Ecology 174: 371-384.

Burton, P.J. 2002. Effects of clearcut edges on trees in the subboreal spruce zone of northwest-central British Columbia. Silva Fennica 36: 329-352.

Cadenasso, M.L. \& Pickett, S.T.A. 2001. Effect of edge structure on the flux of species into forest interiors. Conservation Biology 15: 91-97.

Cadenasso, M.L., Pickett, S.T.A., Weathers, K.C. \& Jones, C.G. 2003. A framework for a theory of ecological boundaries. BioScience 53: 750-758.

Camarero, J.J., Gutiérrez, E. \& Fortin, M.J. 2000. Spatial pattern of subalpine forest-alpine grassland ecotones in the Spanish Central Pyrenees. Forest Ecology and Management 134: 1-16.

Cancino, J. 2005. Modelling the edge effect in even-aged Monterey pine (Pinus radiata D. Don) stands. Forest Ecology and Management 210: 159-172.

Chen, J., Franklin, J.F. \& Spies, T.A. 1992. Vegetation responses to edge environments in old-growth Douglas-fir forests. Ecological Applications 2: 387-396.

Chopping, M., Su, L., Rango, A., Martonchik, J.V., Peters, D.P. \& Laliberté, A. 2008. Remote sensing of woody shrub cover in desert grasslands using MISR with a geometric-optical canopy reflectance model. Remote Sensing of Environment 112: 19-34.

Conti, F., Abbate, G., Alessandrini, A. \& Blasi, C. 2005. An Annotated Checklist of the Italian Vascular Flora. Ministero dell'Ambiente e della Tutela del Territorio, Direzione per la Protezione della Natura. Palombi Ed., Roma, IT.

Cousins, S.A.O. \& Eriksson, O. 2008. After the hotspots are gone: land-use history and grassland plant species diversity in a strongly transformed agricultural landscape. Applied Vegetation Science 11: 365-374.

Davis, M.A., Grime, P.J. \& Thompson, K. 2000. Fluctuating resources in plant communities: a general theory of invisibility. Journal of Ecology 88: 528-534.

Dengler, J., Becker, T., Ruprecht, E., Szabó, A., Becker, T., Beldean, M., Bita-Nicolae, C., Dolnik, C., Goia, I., (...) \& Uğurlu, E. 2012. Festuco-Brometea communities of the Transylvanian Plateau (Romania): a preliminary overview on syntaxonomy, ecology, and biodiversity. Tuexenia 32: 319-359.

Dengler, J., Janišová, M., Török, P. \& Wellstein, C. 2014. Biodiversity of Palaearctic grasslands: a synthesis. Agriculture, Ecosystems \& Environment 182: 1-14.
Didham, R.K. \& Lawton, J.H. 1999. Edge structure determines the magnitude of changes in microclimate and vegetation structure in tropical forest fragments. Biotropica 31 : $17-30$.

Dureau, R. \& Bonnefon, O. 1998. Etude des pratiques de gestion pastorale des coussouls. In: Chambre d'Agriculture, des Bouches du Rhône. (eds.) Patrimoine Naturel et Pratiques Pastorales en Crau, pp. 61-89. CEEP Ecomusée de Crau, SaintMartin de Crau, FR.

Dutoit, T., Buisson, E., Gerbaud, E., Roche, P. \& Tatoni, T. 2007. The status of transition zones between cultivated fields and their boundaries: ecotones, ecoclines or edge effects? Acta Oecologica 31: 127-136.

Ewers, R.M. \& Didham, R.K. 2006. Continuous response functions for quantifying the strength of edge effects. Journal of Applied Ecology 43: 527-536.

Forman, R.T.T. 1995. Land mosaics: the ecology of landscape and regions. Cambridge University Press, New York, NY, US.

Forman, R.T.T. \& Alexander, L.E. 1998. Roads and their major ecological effects. Annual Review of Ecology, Evolution, and Systematics 29: 207-231.

Forte, L., Perrino, E.V. \& Terzi, M. 2005. Le praterie a Stipa austroitalica Martinovsky ssp. austroitalica dell'Alta Murgia (Puglia) e della Murgia Materana (Basilicata). Fitosociologia 42: 83-103.

Fox, B.J., Taylor, J.E., Fox, M.D. \& Williams, C. 1997. Vegetation changes across edges of rainforest remnants. Biological Conservation $82: 1-13$.

Giladi, I., Ziv, Y., May, F. \& Jeltsch, F. 2011 . Scale-dependent determinants of plant species richness in a semi-arid fragmented agro-ecosystem. Journal of Vegetation Science 22: 983-996.

Grime, J.P. 1973. Competitive exclusion in herbaceous vegetation. Nature 242: 344-347.

Hansen, M.J. \& Clevenger, A.P. 2005. The influence of disturbance and habitat on the presence of non-native plant species along transport corridors. Biological Conservation 125: 249-259.

Hardin, G. 1960. The competitive exclusion principle. Science 131: 1292-1297.

Harper, K.A. \& Macdonald, S.E. 2001. Structure and composition of riparian boreal forest: new methods for analyzing edge influence. Ecology 82: 649-659.

Harper, K.A., Macdonald, S.E., Burton, P.J., Chen, C., Brosofske, K.D., Saunders, S.C., Euskirchen, E.S., Roberts, D., Jaiteh, M.S. \& Essen, P.-A. 2005. Edge influence on forest structure and composition in fragmented landscapes. Conservation Biology 19: 768-782.

Hibbs, D.E. \& Giordano, P.A. 1996. Vegetation characteristics of alder-dominated riparian buffer strips in the Oregon Coast Range. Northwest Science 70: 213-222.

Higgins, S., Lavorel, S. \& Revilla, E. 2003. Estimating plant migration rates under habitat loss and fragmentation. Oikos 101: 354-366.

Hylander, K. 2005. Aspect modifies the magnitude of edge effects on bryophyte growth in boreal forests. Journal of Applied Ecology 42: 518-525. 
Jansson, U. 2009. Forest edges in boreal landscapes - factors affecting edge influence. Department of Ecology and Environmental Science, Umea University, Umea, SE.

Keitt, T.H., Urban, D.L. \& Milne, B.T. 1997. Detecting critical scales in fragmented landscapes. Conservation Ecology 1: 1-17.

Laurance, W.F., Lovejoy, T.E., Vasconcelos, H.L., Bruna, E.M., Didham, R.K., Stouffer, P.C., Gascon, C., Bierregaard, R.O., Laurance, S.G. \& Sampaio, E. 2002. Ecosystem decay of Amazonian forest fragments: a 22-year investigation. Conservation Biology 16: 605-628.

Lovejoy, T.E.R., Bierregaard, R.O., Rylands, A.B., Malcolm, J.R., Quintela, C.E., Harper, L.H., Brown, K.S., Powell, A.H., Powell, G.V.N., Schubart, H.O.R. \& Hays, M.B. 1986. Edge and other effects of isolation on Amazon forest fragments. In: Soulé, M.E. (ed.) Conservation biology: the science of scarcity and diversity, pp. 257-285. Sinauer, Sunderland, MA.

MacArthur, R.H. \& MacArthur, J.W. 1961. On bird species diversity. Ecology 42: 594-598.

Mader, H.J., Schell, C. \& Kornacker, P. 1990. Linear barriers to arthropod movements in the landscape. Biological Conservation 54: 209-222.

Mairota, P., Cafarelli, B., Boccaccio, L., Leronni, V., Labadessa, R., Kosmidou, V. \& Nagendra, H. 2013. Using landscape structure to develop quantitative baselines for protected area monitoring. Ecological Indicators 33: 82-95.

Mairota, P., Leronni, V., Xi, W., Mladenoff, D.J. \& Nagendra, H. 2014. Using spatial simulations of habitat modification for adaptive management of protected areas: Mediterranean grassland modification by woody plant encroachment. Environmental Conservation 41: 144-156.

Mairota, P., Cafarelli, B., Labadessa, R., Lovergine, F.P., Tarantino, C., Nagendra, H. \& Didham, R.K. 2015. Very high resolution Earth Observation features for testing the direct and indirect effects of landscape structure on local habitat quality. International Journal of Applied Earth Observation and Geoinformation 34: 96-102.

Matlack, G.R. 1993. Microenvironment variation within and among forest edge sites in the eastern United States. Biological Conservation 66: 185-194.

Mucina, L., Bültmann, H., Dierßen, K., Theurillat, J.P., Raus, T., Čarni, A., Šumberová, K., Willner, W., Dengler, J., (...) \& Peet, R. 2016. Vegetation of Europe: Hierarchical floristic classification system of vascular plant, bryophyte, lichen, and algal communities. Appendix 1. Applied Vegetation Science 19 (Suppl. 1): 3-264.

Pignatti, S., Menegoni, P. \& Pietrosanti, S. 2005. Bioindicazione attraverso le piante vascolari. Valori di indicazione secondo Ellenberg (Zeigerwerte) per le specie della Flora d'Italia. Braun-Blanquetia 39: 1-97.

Pocewicz, A., Morgan, P. \& Kavanagh, K. 2007. The effects of adjacent land use on nitrogen dynamics at forest edges in northern Idaho. Ecosystems 10: 226-238.

Ranney, J.W., Bruner, M.C. \& Levenson, J.B. 1981. The importance of edge in the structure and dynamics of forest islands. In: Burgess, R.L. \& Sharpe, D.M., (eds.) Forest island dynamics in man-dominated landscapes, pp. 67-95. Springer, New York, NY, US.

Raunkiaer, C. 1934. The life forms of plants and statistical plant geography, being the collected papers of C. Raunkiaer. Clarendon Press, Oxford, UK.

Ries, L. \& Sisk, T.D. 2010. What is an edge species? The implications of sensitivity to habitat edges. Oikos 119: 1636-1642.

Ries, L., Fletcher, R.J., Battin, J. \& Sisk, T.D. 2004. Ecological responses to habitat edges: mechanisms, models, and variability explained. Annual Review of Ecology, Evolution, and Systematics 35: 491-522.

Risser, P.G. 1995. The status of the science examining ecotones. Bioscience 45: 318-325.

Saunders, D.A., Hobbs, R.J. \& Margules, C.R. 1991. Biological consequences of ecosystem fragmentation: a review. Conservation Biology 5: 18-32.

Turbé, A., De Toni, A., Benito, P., Lavelle, P., Ruiz, N., Van der Putten, W.H., Labouze, E. \& Mudgal, S. 2010. Soil biodiversity: functions, threats and tools for policymakers. Bio Intelligence Service, IRD, and NIOO. Report for European Commission (DG Environment), Brussels, BE.

Turner, M., Gardner, R.H. \& O'Neill, R.V. 2001. Landscape ecology in theory and practice. Springer, New York, NY, US.

Turtureanu, P.D., Palpurina, S., Becker, T., Dolnik, C., Ruprecht, E., Sutcliffe, L.M.E., Szabó, A. \& Dengler, J. 2014. Scale- and taxon-dependent biodiversity patterns of dry grassland vegetation in Transylvania. Agriculture, Ecosystems $\theta$ Environment 182: 15-24.

Van der Maarel, E. 1990. Ecotones and ecoclines are different. Journal of Vegetation Science 1: 135-138.

Wiens, J.A. 1992. Ecological flows across landscape boundaries: a conceptual overview. In: Hansen, A.J. \& di Castri, F. (eds.) Landscape boundaries, pp. 217-235. Springer, New York, NY, US.

Willems, J.H. 1990. Calcareous grasslands in continental Europe. In: Hiller, S.H., Walton, D.H.W. \& Wells, D.A. (eds.) Calcareous grasslands: ecology and management. Bluntisham books, Cambridge, UK.

Wilson, J.B., Peet, R.K., Dengler, J. \& Pärtel, M. 2012. Plant species richness: the world records. Journal of Vegetation Science 23: 796-802.

Wilson, M.C., Chen, X.Y., Corlett, R.T., Didham, R.K., Ding, P., Holt, R.D., Holyoak, M., Hu, G., Hughes, A.C., (...) \& Laurance, W.F. 2016. Habitat fragmentation and biodiversity conservation: key findings and future challenges. Landscape Ecology, 31: 219-227.

\section{Supporting Information}

Additional Supporting Information may be found in the online version of this article:

Appendix S1. Location map of the study sites. Appendix S2. Descriptor means per plot (A-F). 